\title{
Study on the Seasonality, Habitat and Aspects of Reproductive Behavior of Calicnemia miles (Laidlaw, 1917) (Odonata: Platycnemididae) from Assam, India
}

\author{
Dipti Thakuria $^{1, *}$, Jatin Kalita ${ }^{2}$ \\ ${ }^{1}$ Department of Zoology, Biodiversity and Conservation Laboratory, Gauhati University, India \\ ${ }^{2}$ Department of Zoology, Gauhati University, India
}

Copyright $\bigcirc 2019$ by authors, all rights reserved. Authors agree that this article remains permanently open access under the terms of the Creative Commons Attribution License 4.0 International License

\begin{abstract}
Calicnemia miles (Laidlaw, 1917) is a bright red blood colored, damselfly specialized to waterfalls. Apart from the limited knowledge on the flight season, no prior reports on the breeding biology of the species are available. The present study attempts to describe the seasonality, habitat and behavioral aspects of oviposition in C. miles recorded from Assam. The population of C. miles was recorded during late premonsoon (April-May) and early monsoon season (June-July); peak of flight and copulation was observed in the month of June. The species occupies shady areas near waterfalls and was found to prefer roots of trees, moss carpet and damp seepage of streamlets surrounded by vegetation for mating and oviposition. The female deposits eggs into the plant tissue endophytically. Daily oviposition activity lasts from 80-120 minutes during which the males guards their females in tandem till the entire episode of oviposition.
\end{abstract}

Keywords Damselfly, Endophytic, Oviposition, Habitat, Rani, Kamrup

\section{Introduction}

The species of the genus Calicnemia Strand, 1928 belonging to the family Platycnemididae are damselflies, mainly confined to Southeast Asia, India and China (Lieftinck, 1984). The species are recognizable by its colouration and markings, as well as the form of its genital ligula and anal appendages (Dow et al., 2014). The genus Calicnemia has 24 accepted species worldwide (Schorr and Paulson, 2019) among which 10 species are known to occur from India. (Subramanian and Babu, 2017). In India, Calicnemia miles are known to occur in Sikkim, Darjeeling Himalayas, Himachal Pradesh and Purbanchal (Mitra, 2003).
Each Odonata species occupies a characteristic range of habitat; some of the species are catholic in their choice of habitat whereas some are highly selective (Corbet, 2004). The act of habitat selection has great significance in the life history of Odonates, which plays functional role in placing the eggs in a site optimal for development of eggs and larva (Corbet, 1962). The adults use the visual and tactic cues to select the biotope initially, then the larval habitat and finally the oviposition site in a hierarchical order (Corbet, 2004). Endophytic oviposition is a primary mode of oviposition in Zygoptera (Corbet, 2004). Most species make small incision with the serrated ovipositor through which usually cylindrical eggs are inserted into submerged plant tissue (Miller, 1995). During oviposition, the male guards the female by holding the prothorax with anal appendages while the female oviposits endophytically (Miller, 1995).

No prior information is available in the published literature on the oviposition of this species. Hence, information on the oviposition behaviour of such under recorded species can provide baseline data to predict the breeding strategies and conservation of microhabitat.

\section{Materials and Methods}

\subsection{Study Area}

The study was conducted in Rani Reserve forest situated at $26^{0} 05^{\prime} 31^{\prime \prime} \mathrm{N}$ to $26^{0} 01^{\prime} 15^{\prime /} \mathrm{N}$ altitude and $91^{0} 35^{\prime} 16^{\prime \prime} \mathrm{E}$ to $91^{0} 42^{/} 24^{/ /} \mathrm{E}$ longitude with an altitude ranging from $60 \mathrm{~m}$ to $670 \mathrm{~m}$ above the mean sea level in Kamrup district, Assam, North Eastern India (Devi et. al., 2012). The study area is a 'Mixed Moist Deciduous' forest bordered by hills of Meghalaya on the southern side and Deepor beel on the northern side, covering an area of 4372.380 Hectare. It is considered to be an ecotone transition zone between 
montane subtropical moist broad leaf forest of Meghalaya Plateau and Sub Himalayan moist mixed deciduous forest of Assam Valley (Neli, 2014). The area has an average annual rainfall of $2000 \mathrm{~cm}$ and the temperature within the range of $10^{\circ} \mathrm{C}$ to $32^{\circ} \mathrm{C}$ approximately.

\subsection{Survey}

The survey was carried out from 2015 to 2017 along the narrow seasonal stream in the study area. The specimens were photographed and collected for further identification. On every visit the species was searched and reproductive behavior was studied whenever spotted in pairs. The oviposition duration was recorded from initial contact of the abdomen with the plant tissue until the last contact (Martens, 1992) and the behavioral repertoire after copulation were noted. The depth of water was measured and the plant material chosen by the female for oviposition were identified. Water temperature at $1 \mathrm{~cm}$ depth, air temperature in the shade and speed of water flow was measured at the same time.

\section{Results}

A total count of 22 mature individuals (12 males and 10 females) was recorded during the survey. The abdomen of the male is blood red in colour (Figure1) and can be easily distinguished from the female in which the abdomen is pale brown (Figure 2).

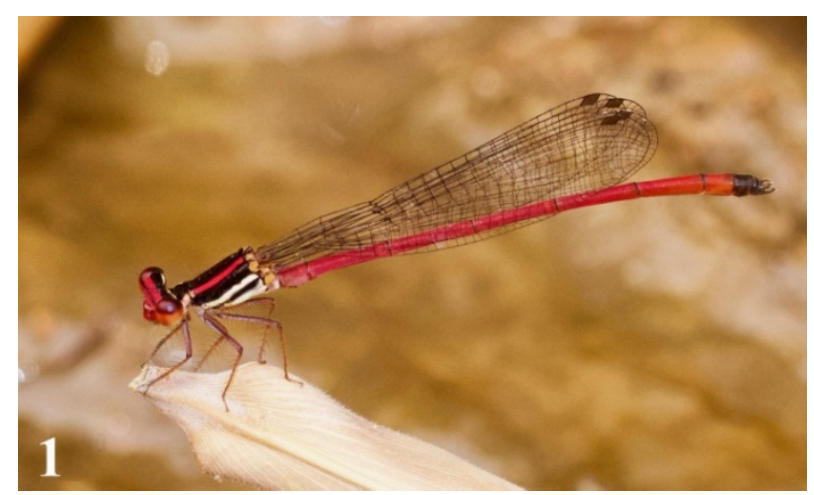

Figures 1. Calicnemia miles, male

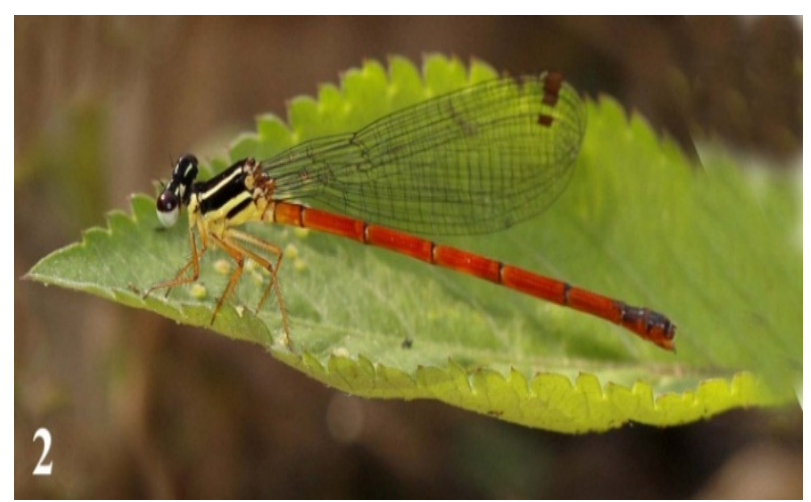

Figure 2. C. miles, female

\subsection{Habitat}

The species was observed to remain confined in semi-terrestrial habitat that generally remains damp with seepage of waterfall flowing from forested stream at an altitude of $120 \mathrm{~m}$ a.s.1. (Figure 3). The shallow streamlets on which the species was observed passes through damp rocks covered by mosses and algal mats in a shaded area. The speed of water flow was moderate $(40 \mathrm{~cm} / \mathrm{min})$, narrow in size $\left(50 \mathrm{~cm}\right.$ wide) and water temperature ranges from $19^{0}$ $\mathrm{C}$ to $20^{\circ} \mathrm{C}$; air temperate is in between $28^{\circ} \mathrm{C}$ to $32^{\circ} \mathrm{C}$. Oviposition was observed to occur in the tissue of partially submerged plants usually in rootlets of plants, algal mats and on litter bed.

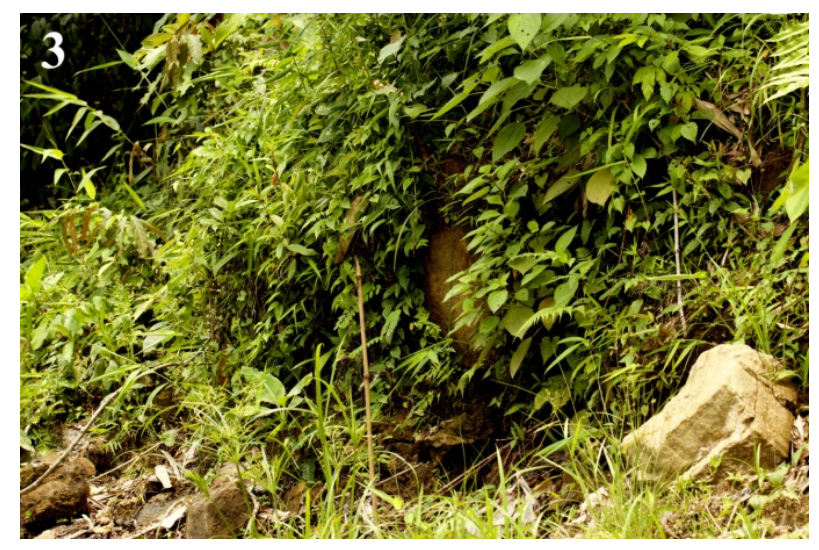

Figure 3. Habitat

\subsection{Seasonality}

In the present survey, the species have been reported from Assam at $\left(26^{0} 01^{\prime} 27.18^{/ /} \mathrm{N}\right.$ to $\left.91^{0} 36^{\prime} 42.29^{/ /} \mathrm{E}\right)$ in Rani Reserve forest at the lowest altitude (120m a.s.1). Significant reproductive populations of Calicnemia miles were located during the late premonsoon (April, May) and early monsoon season (June, July). An initial population was observed in the end of April and May with peak of flight and copulation towards June and gradually declining towards July. With the present records of adult C.miles in April, May, June, July the flight season of the species is observed to be from April to July.

\subsection{Observations on Oviposition Behaviour}

Prior to copulation, it was observed that the males neither defend the reproductive site against other competing males nor did they show any courtship display to attract the females for copulation. Of the total 22 individuals, 7 pairs were seen copulating and all the males were seen waiting for the females next to the edge of water (bank vegetation). When the female came nearby water body, the male immediately seized the female through the prothorax and copulated successfully. The entire oviposition episode was observed completely and it was found that $C$. miles is highly selective in the selection of 
their habitat. After copulation, the male guarded his partner in tandem that lasted till the end of oviposition. No female was ever seen ovipositing alone. The sequence of events that are observed during oviposition are described under as follows-

1. The pairs in tandem searched for oviposition substrate for an average of $30 \mathrm{~min}$ which is termed as 'exploratory' activity by Bick and Bick, 1963. It included numerous flights between which the female perched and curved her abdomen ventrally, thereby probing the substrate with the ovipositor 8-9 times during which the female slightly swung its abdomen from side to side.

2. After selection of the suitable substrate like floating rootlets of plants, the female settles on or nearby it. The female adopts either horizontal posture or hung vertically on the floating rootlets with the ovipositor touching the water and raises her abdomen irregularly through $5^{\circ}-20^{\circ}$. Meanwhile, the male takes up a rigid, erect or sentinel position by clasping the prothorax of the female with anal appendage. The female then align herself by holding on to the twigs of dead plant, plant tissue or on the damp rock itself (Figure 4A, 4B, 4C.).

3. Oviposition occurred immediately after the copulation ceases at the distance of $1-2 \mathrm{~m}$ in the same characteristic range of habitat from the site of mating. The mode of oviposition is endophytic in which the female makes small incision on the plant rootlets with the ovipositor, inserting the eggs on it. The plant on which the oviposition occurred was identified as Mikenia micrantha belonging to the family Asteraceae. The rootlets were partially submerged (1-2mm depth) and the rate of water flow was very slow $40 \mathrm{~cm}$ per minute.

4. After complete insertion of the ovipositor, the female stayed motionless, moving the tip of abdomen at very low amplitude. There occurred distinct shifts for 7-8 times in between the entire duration of oviposition to nearby substrate or change in position by climbing up the rootlets on the same plant, often taking off and relanding on the same site, discernible for oviposition. After the completion of egg laying into the slits made by the ovipositor, the female removes the ovipositor, keeping her abdomen curved ventrally and making repetitive movements. The entire oviposition activity lasted for 80-120 minutes.

5. After the end of oviposition, the pair breaks the tandem that was initiated by the female by making jerks with her abdomen rhythmically. The female then flies off to another perch, rocks her head, curves her abdomen ventrally towards thorax for wiping the head vigorously with forelegs and ovipositor is cleaned by brushing movements of the hind legs (Figure 5).
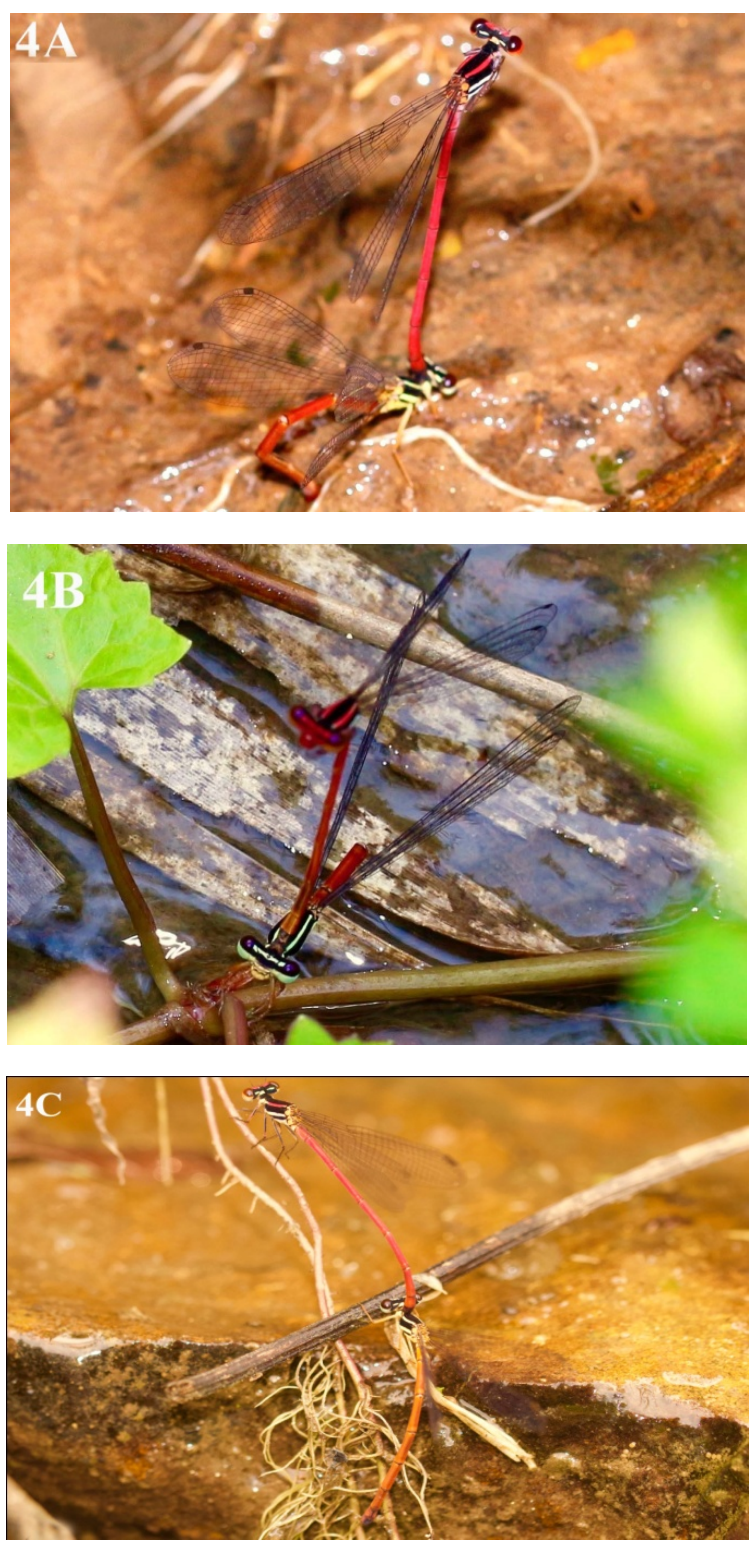

Figure 4. A. Ovipositing C. miles, female holding the damp rock and male in sentinel position; B. C. miles female holding dead twigs of plant \& male in sentinel position; C. C.miles male in tandem with ovipositing female on plant rootlets;

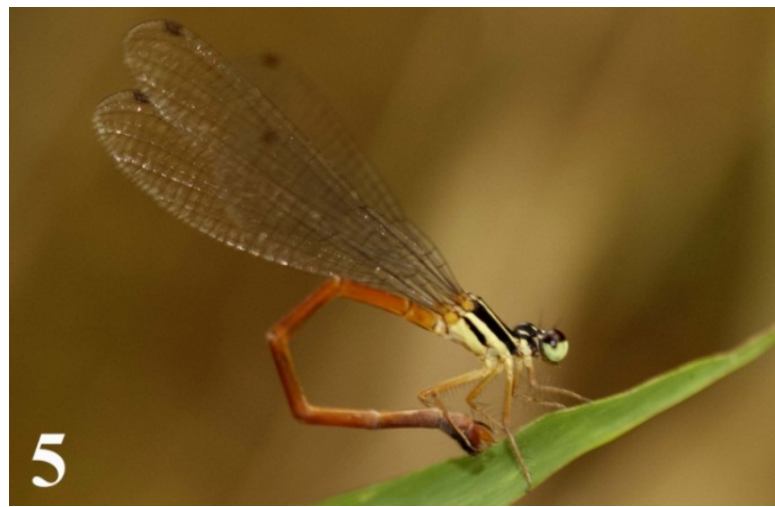

Figure 5. Female cleaning the ovipositor with hind legs 


\section{Discussion}

Calicnemia miles were previously reported only from Himachal Pradesh and Sikkim (Fraser, 1933). The lack of records from other parts of North East India is may be due to the lack of surveys conducted in the potential habitats covering this area. The observation of the species at $\left(26^{0}\right.$ $01^{\prime} 27.18^{/ /} \mathrm{N}$ to $91^{0} 36^{\prime} 42.29^{\prime /} \mathrm{E}$ ) in Rani Reserve forest is at the lowest altitude (120m a.s.1) at present that signifies the extension of the altitudinal range of the species. These high counts of mature individuals in the early monsoon together with the presence of tenerals throughout the study period might indicate regular additions to the population by new emergences from April to early part of July.

Our study revealed that the males of C.miles are non-territorial in the reproductive site and did not defend against rivals. The matured males usually wait at the edge of bank vegetation for female to arrive as mate selection tactic. Similar findings were reported by Khelifa et. al., (2016) in Platycnemis dilatata. C.miles is highly selective species and remained confined to semi terrestrial habitat in forest on wet rocks during reproductive period. The rocks being kept damp by seepage of stream waterfall surrounded by organic litter, algal mats and ferns. However, Kumar \& Prasad (1977) reported that larvae of Calicnemia miles inhabits semi terrestrial habitat of damp soil covered with thick carpet of mosses and fungi near waterfalls on vertical hill rocks of Western Himalayas which confirms the habitat selection of adult species. Moreover, Calicnemia carminea pyrrhosoma also occupies a thick carpet of moss and ferns on vertical rocks near waterfalls in the Western Himalayas as reported by Kumar (1976), Kumar and Prasad (1977). However, Leiftinck in 1984 reported that two congeneric members Calicnemia chaseni and Calicnemia rectangulata inhabiting the hills and mountains are also found to occur in ponded streams and marshes fed by clear water, possibly flowing from springs.

The exploratory activity conducted by pairs in tandem prior to oviposition might indicate check for the presence of predators and suitability testing of substrates, which was also reported by Martens (1992). The mode of oviposition in C.miles is found to be endophytic in which the female deposits her eggs on the floating horizontal or vertical rootlets of plant tissue, algal mats; just touching the water surface almost on a dry stream. Eggs laid onto the rootlets of plant tissue may essentially have some ecological requirements like minimal water loss, protected habitat for eggs and larval development. Similar findings was reported by Dawn (2019) on the oviposition site in C.eximia and C.miniata where the species were seen to oviposit in wet moss, leaf litter and fallen plant tissue of the similar habitat. Further, presence of larvae of C.eximia in the similar habitat (Dawn, 2019) confirms unique selection of oviposition site of this genus. However, the long duration 80-120 minutes and discontinuous mode of oviposition in C.miles also corresponds to other members like Platycnemis (Furtado, 1974) belonging to the same family, Platycnemididae. The Contact guarding postcopulatory behavior exhibited by the male lasted from exploratory phase to the entire duration of oviposition were also reported in Copera by Chowdhury and Karim in 1994; and Platycnemis (Heymer, 1966) belonging to the family Platycnemidae. Dawn (2019) also reported that males of C.eximia guarded the female in contact during oviposition. The main function of tandem formation may be probably to reduce other male interference during oviposition (Jacob, 1955) and also to get an extra power of flight (Andrew et. al., 2011). During oviposition, the male holds the female by the prothorax and takes up a rigid, sentinel posture. This posture of male could probably command a wider view of the surrounding, thereby reducing the risk of predation by frogs (Rehfeldt, 1991) and helps in protecting the genetic investment of eggs (Corbet, 2004). Mate guarding, a post copulatory behavior observed in male is considered to have evolved in the context of sexual selection, to protect a male's sperm investment from conspecific males competing for fertilizations (Parker, 1970; Alcock, 1979; Waage, 1979; Sillen-Tullberg, 1981).

Eggs already deposited restrict the available space for further deposition of eggs (Martens 1992) which could be the probable reason for the change in shifts or position during oviposition, thereby allowing the female to distribute her eggs in different sites. Yet, another reason for such shifts could be the presence of natural obstacles like floating leaves or drifting material lying in close proximity to the oviposition substrate (Martens 1992).

Calicnemia miles is a stenotypic species and is highly sensitive to changes in their habitat. The grave and accelerating destruction of habitats may cause serious threats to such habitat specific group of Odonate species. Therefore, information on various ecological aspects of such under recorded species provides the baseline data from which conservation measures to maintain the ecosystem health can be formulated.

\section{Acknowledgements}

We are very grateful to the Assam State Biodiversity Board granting permission to conduct study in Rani Reserve Forest, Assam, India. DT is thankful to UGC for aiding with BSR fellowship. DT extends her heartiest thanks to Paris Basumatary, Sangeeta Das and Nilutpal Mahanta for their immense help and support. DT is grateful to Prosenjit Dawn for constructive comments in the manuscript. We are also very grateful to anonymous reviewers for their valuable suggestions in improving the original manuscript. 


\section{REFERENCES}

[1] A. Heymer. Etudes compare du comportcment inne de Platycnemis acutipennis Selys 1841 et de Platycnemis latipes Rambur 1842 (Odon. Zygoptera), Annales De La Societe Entomologique De France, 2 (1): 40-45, 1966.

[2] A. Kumar. Biology of Indian dragonflies with special reference to seasonal regulation and larval development. Bulletin of Entomology, New Delhi, 3: 37-47, 1976.

[3] A. Kumar, M. Prasad. Odonata of Ponds, Tanks and Paddy fields at and around the Dehra Dun Valley. (W. Himalaya), Newsletter Zoological Survey of India, 3(5): 270-273, 1977.

[4] A. Martens. Egg deposition rates and duration of oviposition in Platycnemis pennipes (Pallas) (Insects: Odonata), Hydrobiologia, 230(1): 63-70, 1992.

[5] B. Sillen-Tullberg. Prolonged copulation: a male 'postcopulatory' strategy in a promiscuous species, Lygaeus equestris (Heteroptera: Lygaeidae), Behaviour Ecology and Sociobiology, 9: 283-289, 1981.

[6] G.H. Bick, J.C. Bick. Behavior and population structure of the damselfly Enallagma civile (Hagen) (Odonata; Coenagriidae), Southwestern Naturalists, 8: 57-84, 1963.

[7] G.A. Parker. Sperm competition and its evolutionary consequences in the insects. Biological Reviews, 45 (4): $525-567,1970$

[8] G.E. Rehfeldt. Site-specific mate-finding strategies and oviposition behavior in Crocothemis erythraea (Brullé) (Odonata: Libellulidae), Journal of Insect Behavior, 4(3): 293-303, 1991.

[9] H.S. Devi, A. Pinokiyo, S.K. Borthakur. Vegetation cover and forest structure assessment in Rani and Garbhanga Reserve Forests, Assam using remote sensing and GIS, 2012.

[10] J.I. Furtado. The reproductive behavior of Ischnura senegalensis (Rambur), Pseudagrion microcephalum (Rambur) and $P$. perfuscatum Lieftinck (Odonata, Coenagrionidae), Malaysian Journal of Science, 1: 57-69, 1972.

[11] J.I. Furtado. The reproductive behaviour of Copera marginipes (Rambur) and $C$. vittata acutimargo (Kruger) (Zygoptera: Platycnemididae). Odonatologica, 3: 167-177, 1974.

[12] J. Alcock. Multiple mating in Calopteryx maculata (Odonata: Calopterygidae) and the advantage of non-contact guarding by males, Journal of Natural History, 13: 439-446. 1979.

[13] J. K. Waage. Dual function of the damselfly penis: Sperm removal and transfer. Science, 203 (4383): 916-918, 1979.

[14] K.A. Subramanian, S. Ali, T.V. Ramchandra. Odonata as indicators of riparian ecosystem health a case study from south western Karnataka, India, Fraseria (NS), 7:83-95, 2008.

[15] K. A. Subramanian, R. Babu. Checklist of Odonata (Insecta) of India. Version 3.0, 2017.

[16] M.E. Jacobs. Studies on territorialism and sexual selection in dragonflies, Ecology, 36: 566- 586, 1955.
[17] M.A. Lieftinck. Further notes on the specific characters of Calicnemia Strand, with a key to the males and remarks on some larval forms (Zygoptera: Platycnemididae), Odonatologica, 13:351-375, 1984.

[18] M. Schorr, D. Paulson. World Odonata List. Electronic Database accessible at http://www.pugetsound.edu/academ ics/academic-resources/slater-museum/biodiversity-resouc es/dragon flies/world-odonata-list2/, 2013.

[19] P.S. Corbet. Biology of Dragonflies, H. F. \& G. Witherby Ltd, 1-30, 1962.

[20] P.L. Miller. Dragonflies. Richmond Slough, UK, 118, 1995.

[21] P.S. Corbet. Dragonflies: Behaviour and ecology of Odonata (Revised Edition) Colchester, UK: Harley Books, 9 43,427-558, 2004.

[22] P. Dawn. Description of the last instar larva of Calicnemia eximia (Selys, 1863) (Odonata: Platycnemididae) from West Bengal, India. Zootaxa, 4657 (1): 183 - 187, 2019.

[23] R.J. Andrew, N. Thaokar, A.A. Dhamani. Sentinel position of the male during oviposition in the damselfly Ceriagrion coromandelianum (Fabricius) (Insecta: Odonata), Hexapoda, 18(1): 24-32, 2011.

[24] R.A. Dow, A.H.M.E.D. Zia, M. Naeem, M.A. Rafi. Calicnemia fortis sp. nov. from Pakistan (Odonata: Zygoptera: Platycnemididae), Zootaxa, 3869(3): 338-342, 2014.

[25] R. Khelifa, et al. Reproductive behaviour of a North African endemic damselfly, Platycnemis subdilatata (Odonata: Platycnemididae) and probable senescence effects. International Journal of Odonatology 19.3: 157-167, (2016)

[26] S.H. Chowdhury, N. Karim. Observations on the reproductive behaviour of Copera annulata (Selys), Advances in Oriental Odonatology (Ed. V.K. Srivastava), 69-76, 1994.

[27] S. Neli. Studies on the insect pollinators of Rani reserve forest Assam India, 2014.

[28] T.R. Mitra. Ecology and biogeography of Odonata with special reference to Indian fauna, Zoological Survey of India, 2003. 